\title{
The Perception of a Woman's Love in a Relationship with a Prisoner is Erotic and Altruistic
}

\author{
Giebel $\mathrm{G}^{*}$ and Elbert T
}

Department of Psychology, University of Konstanz, Germany

${ }^{*}$ Corresponding author: Giebel G, Department of Psychology, University of Konstanz, Germany, E-mail: gilda.giebel@uni-konstanz.de

Citation: Giebel G, Elbert T (2014) The Perception of a Woman's Love in a Relationship with a Prisoner is Erotic and Altruistic. J Forensic Sci Criminol 2(1): 102. doi: 10.15744/2348-9804.1.402

Received Date: September 30, 2013 Accepted Date: February 11, 2014 Published Date: February 13, 2014

\begin{abstract}
Studies have reported the effects of imprisonment on the wives and girlfriends of prisoners, but have not investigated how these women perceive love and commitment. This study analyzes four different styles of love: eros (romantic love), storge (amicably love), mania (possessive love), and agape (altruistic love) in a sample of 96 women who are in relationships with prisoners. The same love styles were compared to a control sample of $\mathrm{N}=96$ women. They were selected from a larger sample of 859 women such that the variables age and duration of the relationship of the two groups were matched. Results show that women in relationships with prisoners score higher on the eros and agape love styles in comparison to the women from the control group. Those women who stay in love with prisoners seem to endure the negative consequences of their partners imprisonment through feelings of deep love, commitment, and altruistic care.
\end{abstract}

\section{Introduction}

Women who are in relationships with prisoners are exposed to a variety of serious problems, such as financial problems, loneliness, sexual frustration, raising children alone, and stigmatization [1-4]. Several studies examined the daily problems and needs of women whose partners are imprisoned but did not analyze the love relationships of the couples [5]. How do these women perceive their relationships? Which styles of love, like romantic passion or friendship, are predominant?

Megan Comfort (2008) interviewed 50 women who were in a relationship with inmates of the San Quentin State Prison, California. Categories of three types of women were detected by Comfort [6]. The patterns for the categorization included the circumstances in which the partners met each other and factors which contribute to the loyalty during imprisonment. The first type consists of women who got to know their partners when their partners were imprisoned. These women indicated high levels of satisfaction and romantic commitment in their relationships. Women who got to know their partners before their imprisonment and showed high levels of loyalty, even when their partners were in prison several times before, belong to the second category. The third category, described by Comfort, consists of women who felt safer and more satisfied during the time of imprisonment of their partner, because they evaluate the spatial distance to their partners as stabilization for their relationships, especially if they suffered from frequent fights and domestic violence. Concerning women who fell in love with prisoners during their imprisonment we found consistent observations and conclusions in the literature. These women perceived their relationship as something special and their partners as very romantic, sympathetic and caring [6-8]. Previous investigations of the topic generated interesting qualitative studies, but quantitative analyses with a control group comparison of women who are not in relationships with prisoners were not established.

A standardized instrument for measuring different styles of love distinguished six different love styles: eros (romantic love), ludus (playful love), storge (amicably love), pragma (pragmatic love), mania (possessive love), and agape (altruistic love) [9]. In her book, "Women Who Love Men Who Kill," Sheila Isenberg characterized the love between prisoners and their partners as a romantic passion (eros) which gets inspired by deprivation [7]. Capturing the eros love style is particular important for this study. We were also interested in testing the love styles storge, mania and agape. We omitted the love styles pragma and ludus, because we found no evidence in literature that women love prisoners for pragmatic reasons, like financial or status benefits or that these women celebrate a playful style of love with prisoners and other short-term partners.

On the other hand we found evidence that some women in love with prisoners evaluate their relationship as not sexual, but rather as a sort of companionship (storge) [7]. Women who stays with their partners are imprisoned later on could be highly dependent, uncertain and possessive (mania). We did not find concrete evidence for that assumption in the literature, but wanted to examine it. The love towards men in prison appears selfless, caring, and altruistic because the women have to endure loneliness and stigmatization and they cannot be sure that their effort will pay off one day. As a matter of fact we also assayed the Agape love style. 
In this study, we tested these four of the six different love styles (eros, storge, mania, and agape) for women who are in a relationship with prisoners and compared the results about women whose partners are not imprisoned, but are the same age and in a relationship with the same duration.

Our hypothesis was that women in relationships with prisoners have higher scores in the eros love style than women in relationships with men who are not imprisoned.

\section{Methods}

\section{Participants}

Ninety-six German and Swiss women who were in a relationship with a prisoner participated in this study (Age: $M=$ 32.77, 17- 63; duration of the relationship: 0.10 - 46 years, $M$ $=5.54 ; S D=7.086) . N=78$ women answered the survey online, most of whom were acquired from an advertisement in www.knastcafe.de. Eighteen women answered a written, pen and paper version of the questionnaire. These women were asked to participate by four different chaplains in various prisons in Germany $(\mathrm{N}=9)$ and by staff of the JVA Pöschwies, Switzerland $(\mathrm{N}=9)$. The crimes of the partners were mainly bodily injury (39), robbery (27), narcotics offense (25), rape (11), fraud (7), child assault (6), and seven other types of offenses. Twenty-eight men were convicted for two or more different offenses. Ninety women read either the verdict or were informed by the therapist about the offense of their partner. Eighty-three women were in a relationship with their partner before he was imprisoned. Nine women have a platonic relationship.

The control group consisted of 859 female staff and students from the University of Konstanz who participated in the online study. Ninety-six women were chosen in such a manner that they matched in the variables age and duration of the relationship with the women who have a partner in prison (Age: $\mathrm{M}=32.77,17-62$; duration of the relationship: 0.10- 44 years, $M=5.94 ; S D=8.16$ ). This control sample differs from the sample of women with partners in prison in the education level and maternity. Women with men in prison were more often mothers ( $\mathrm{N}=62$ versus $\mathrm{N}=26)$ and more often finished an apprenticeship $(\mathrm{N}=65$ versus $\mathrm{N}=40)$, but fewer attended college or university $(\mathrm{N}=12$ versus $\mathrm{N}=48)$.

\section{Material}

We used four subscales of the "Marburger Einstellungs-Inventar zu Liebesstilen (MEIL)" [10], which is a validated and standardized German instrument used to measure different love styles. It is partially based on six basic love styles that were investigated by Lee and Hendrick \& Hendrick [9,11 ]. The instrument measures the love styles named eros, stroge, ludus, pragma, mania, and agape using 10 items for each subscale on a nine-point Likert scale. We selected the four scales eros, storge, mania, and agape for this study. Eros describes a romantic and erotic type of love with strong commitment, whereas storge reflects love as deep friendship and a solid, down to earth relationship. Mania describes a possessive style of love with little freedom in the relationship and the propensity for intense jealousy. The scale agape captured an altruistic style of love with the effect that people focus on the needs of their partner and try to do anything and everything to help him or her. We simplified some of the original items to make sure that participants with a lower level of education would understand all of the questions (see Appendix). Cronbachs a ranged from .82 to .91 for each scale.

\section{Procedure}

The participants received either the pen and paper version of the questionnaire or completed the identical online version. First, demographic variables and information about the relationship and about the offence of their partner were ascertained. The participants answered the 40 items from the MEIL. Women in the control group did not receive questions concerning the imprisonment. Participants received no financial compensation. All participants gave informed consent. The ethical review board of the University of Konstanz approved the study.

\section{Results}

We found a significant difference in eros (Figure1) and agape, (Figure 2) but not in storge and mania between the women with partners in prison and the control group of women. Women with men in prison have higher values in the love style eros (women with partners in prison: $M=7.75, S D=1.21$ control group: $M=6.70, S D=1.45 t_{187}=5.39, p<.001, d=.79$ ) and agape (women with partners in prison: $\mathrm{M}=6.54, \mathrm{SD}=$ 1.77 control group: $M=5.94, S D=1.30 t_{172.17}=2.69, p=.008$, $d=.39$ ) than women with partners who are not in prison.

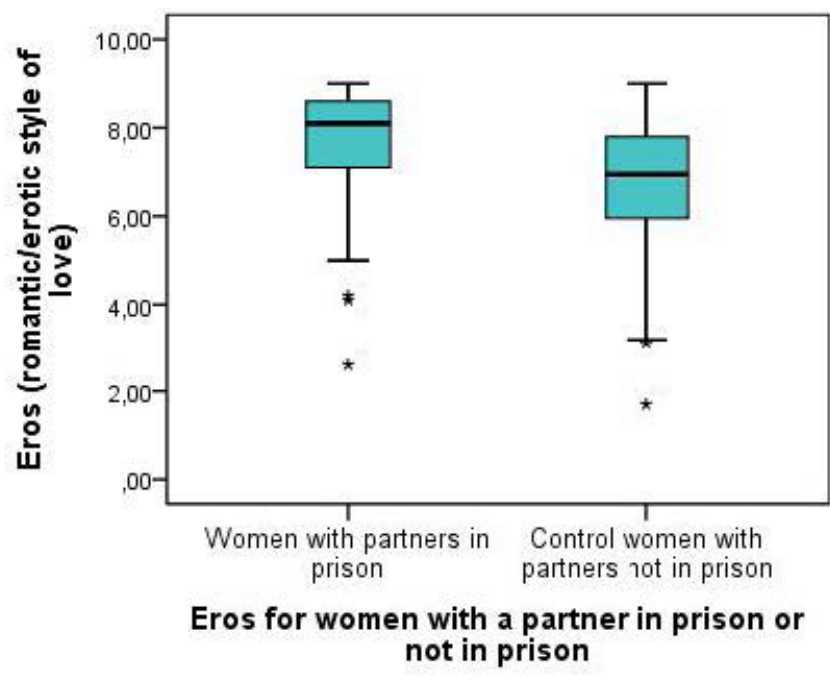

Figure 1: Boxplots eros love style for women with partners in prison and control group of women

A linear regression analyze for the factor eros confirmed the effect of the variable imprisoned partner and revealed an additional effect of the variable university degree, but revealed no further influence of the variables finishing an apprentice- 


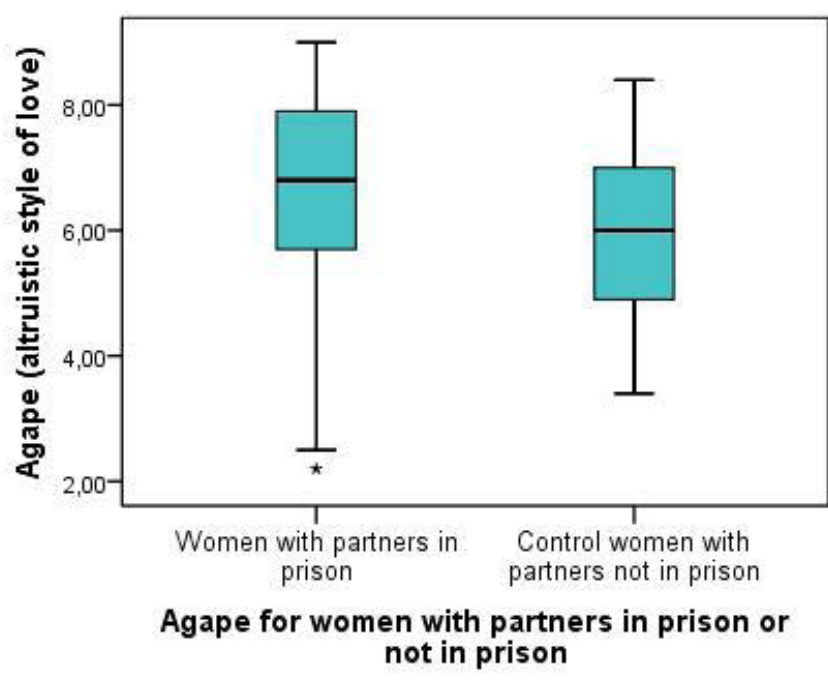

Figure 2: Boxplots agape love style for women with partners in prison and control group of women

ship or being a mother (Table 1). An imprisoned partner and a university degree predict higher scores in eros love style in women. A linear regression analyze for the factor agape revealed an influence on the variables, loving a partner in jail, being a mother and finished an apprenticeship (Table 2). Loving an imprisoned partner, being a mother and have not finished an apprenticeship predict higher scores in agape love style in women. Most of the women in our sample started the relationships before their partners became imprisoned. Only 13 women got to know their partners as prisoners. These two groups of women do not differ from each other in any of the love styles. We also differentiated the women regarding the offense of their partner, e.g., if it was a sexual crime. Again, we found no significant difference for any of the love style subscales.

\section{Discussion}

Women who are in a relationship with prisoners perceive their own feelings for their partners as highly romantic and erotic and they feel a strong commitment to their partners. This result confirms our hypothesis and coincides with Sheila Isenberg's [7] observation that women in love with prisoners view their relationships as something special, as "true love" which is deep, romantic, and full of passion. Because of the cross-sectional design of this study, we do not know the causality between the high scores of eros love and the effect of the imprisonment of the partner. These women could be so attracted to extreme male dominance and aggression with an almost hybristophilic character that they actually have chosen aggressive men who had the potential to become delinquent and convicted of a crime in the future. We did not find studies about hybristophilia, but empirical evidence for the phenomenon that women felt attracted by appetitive aggressive men for a short-term relationship [12]. Another explanation could be that the women are only able to endure their difficult situation if they really love their partners deeply and without any doubts. Women who have started the relationship before their partners became imprisoned and those who started the relationship during the imprisonment do not differ from each other in any of the love styles. Furthermore, the reason for the conviction and ergo the severity of the crime had no effect on the different love styles. These findings could be influenced by the small sizes of subsamples. Until researchers find no differences between these different groups, we interpret our results more in the direction that women maintain their relationships with men in prison only if they feel deep romantic love for them and not because they all have hybristophilic tendencies. As a limitation of this study we should consider that the women's answers could be subject to cognitive biases. A relationship with a prisoner is socially not appreciated and women who participated in this study expect that the results will be published. The eros style of love is eminently respectable. Maybe women who are in a relationship with prisoners try to present their relationship in a very positive manner according to the motto: True love knows no limits. What speaks against such a bias of social desirability is the result that women with their partners in prison did not differ from the control group regarding the love style mania, which is a socially more undesirable love style.

\begin{tabular}{|c|c|c|c|c|}
\hline \multicolumn{5}{|c|}{ Eros Love Style $(\mathrm{N}=192)$} \\
\hline Variable & B & SE & $\beta$ & p \\
\hline Imprisoned Partner & 1.22 & 0.21 & 0.43 & 0.000 \\
\hline University Degree & 0.47 & 0.23 & 0.15 & 0.038 \\
\hline \multicolumn{2}{|c|}{$\mathrm{R}_{\text {adi }}^{2}$} & \multicolumn{2}{|c|}{.15} & \\
\hline
\end{tabular}

Table 1: Summary of Hierarchical Regression Analysis for Variables Predicting

\begin{tabular}{|c|c|c|c|c|}
\hline \multicolumn{5}{|l|}{ Agape Love Style $(\mathrm{N}=192)$} \\
\hline Variable & B & SE & $\beta$ & $\mathbf{p}$ \\
\hline Imprisoned Partner & 0.55 & 0.24 & 0.17 & 0.026 \\
\hline Being A Mother & 0.50 & 0.24 & 0.16 & 0.039 \\
\hline Finished An Apprenticeship & -0.50 & 0.23 & -0.26 & 0.023 \\
\hline \multicolumn{2}{|l|}{$\mathrm{R}_{\text {adj }}^{2}$} & \multicolumn{2}{|c|}{.06} & \\
\hline
\end{tabular}

Table 2: Summary of Hierarchical Regression Analysis for Variables Predicting

Women who are in relationships with men in prison score higher in agape, the altruistic love style, than the women in the control group. The daily life of these women grew more complicated because of the imprisonment: Most of them have to find a job because they lost their main earners; they have to console their children, who lost their father, and have to explain them where he is; perhaps they have to deal with the fact that their partners have lied to them and committed a violent crime [13]. They are only allowed to visit their partners for 30 minutes in a visitor room two times a month (example of the JVA Freiburg, Germany) and they try to support their partners emotionally by writing letters, organizationally by finding a good lawyer, and financially by sending care packages to the prison. Their lives changed completely with the imprisonment of their partners and it is not surprising that they perceive their love relationship as more altruistic and selfless in comparison to the control group of women. The altruistic love style is also higher for women who are mothers and who did not finished an apprenticeship. Although the result for al- 
truistic love style is significant, the explained variance in the regression model is small. The factor eros love style is more determining.

This study shows that women who are in a relationship with prisoners describe their love as highly romantic, erotic, with a huge amount of commitment, and an altruistic focus on the needs of their partners.

\section{Acknowledgement}

Research was supported by the Deutsche Forschungsgemeinschaft.

\section{References}

1. Comfort M, Grinstead O, McCartney K, Bourgois P, Knight K (2005) 'You Can't Do Nothing in This Damn Place': Sex and intimacy among couples with an incarcerated male partner. J Sex Res 42: 3-12.

2. Hannem SN (2009) Marked by association: Stigma, marginalisation, gender and the families of male prisoners in Canada. Carleton University, Ottawa.

3. Morris P (1965) Prisoners and their families. Hart Publishing Company,

New York.
4. Schneller DP (1976) The prisoner's family: a study of the effects of imprisonment on the families of prisoners. $\mathrm{R}$ and E Research Associates, San Francisco.

5. Daniel SW, Barrett CJ (1981) Needs of prisoners' wives: A challenge for the mental health professions. Community Mental Health Journal 17: 310-322.

6. Comfort M (2007) Doing time together: Love and Family in the Shadow of the Prison. University of Chicago Press, Chicago.

7. Isenberg S (1991) Women who love men who kill. Simon \& Schuster New York.

8. Pfister E (2013) If women love criminals. Christoph Links Verlag GmBH, Berlin.

9. Hendrick C, Hendrick S (1986) A theory and method of love. J Pers Soc Psychol 50: 392-402.

10. Bierhoff HW, Grau I, Ludwig A (1993) Marburger setting inventory for Love Styles. Göttingen: Hogrefe.

11. Lee JA (1973) The colors of love: An exploration of the ways of loving. Don Mills, Ontario: New Press.

12. Giebel G, Weierstall R, Schauer M, Elbert T (2013) Female attraction to appetitive- aggressive men is modulated by the women's menstrual cycle and men's vulnerability to traumatic stress. Evol Psychol 11: 248-62.

13. Kern J (2002) The situation of women and partners of prisoners. (Diploma), Alber-Ludwigs-University of Freiburg, Freiburg. 